\title{
Tuffen West FLS, FRMS (1823-1891): artist of the microscopic, naturalist, and populiser of microscopy
}

\section{Tuffen West FLS, FRMS (1823-1891) : artiste naturaliste, iconographe et pionnier de la microscopie scientifique}

\author{
John R. Dolan ${ }^{1}$ \\ ${ }^{1}$ Sorbonne Université CNRS, Laboratoire d'Océanographie de Villefranche-sur-Mer, Station Zoologique, 06230 \\ Villefranche-sur-Mer, France, dolan@obs-vlfr.fr
}

\begin{abstract}
Tuffen West is known today as a British engraver and lithographer, active in the last half of the 19th century, who produced illustrations of the microscopic for the scientific and popular press. However, in his time, he was also recognized as a naturalist. He was 'FLS', an elected Fellow of the Linnean Society of London, also 'FRMS', an elected member of the Royal Microscopical Society, and authored many articles in scientific and popular journals. Tuffen West was then much more than a 'microscopic artist' as he described himself. In this appreciation of Tuffen West, his troubled life is reviewed, his considerable contributions as an illustrator are documented, and his achievements as a naturalist and populiser of microscopy are shown.

KEYWORDS. scientific illustration, microscopy, 19th Century biology, popular science, lunacy.
\end{abstract}

\section{Introduction}

Tuffen West has been described as the most famous illustrator of the microscopic of his time (Turner 1974). However, he was also a naturalist in his own right, and a very active populariser of microscopy (Lightman 2016). Details of these latter activities, as well as the subject breadth of the illustrations West produced, which went well beyond the microscopic, are not well known, as are the details of his troubled life. Here I present an appreciation of Tuffen West through first a short biography, followed by summaries of his work: first as an illustrator, then as a naturalist, and finally as a populariser of microscopy. The goal of this appreciation is to shine a light on the little known aspects of both the life and work of Tuffen West.

\section{Biographical Sketch of Tuffen West}

The following biographical sketch is based, except where noted, on an obituary authored by an anonymous, but self-described close friend of Tuffen West (Anon. 1891). Tuffen West was born on August 15, 1823, into a Quaker family of some distinction. His father, William West, was a chemist and druggist. In 1831, when Tuffen West was but 8 years of age, his father was one of the founding members of the British Association for the Advancement of Science, and was of some importance in the Association (Morrell \& Thackray 1981). He was later elected to the Royal Society (Cheetham \& Reynolds 1889). Tuffen West was educated at the Quaker School of York, now known as Bootham School. He is said to have been an avid naturalist, a collector of plants and skeletons, already as a schoolboy. His father chose a medical career for him. At age 15 he was an apprentice surgeon with Henry Brady. However he appears to have retained his interest in natural history. At age 19 he won a $3 £$ prize, a considerable sum for the time, for his essay "The comparative anatomy of birds" (Anon 1842). His path to a medical career altered abruptly towards the end of his apprenticeship in 1845. In his father's chemistry laboratory, an experiment went awry with an explosion that resulted in a permanent hearing loss, rendering Tuffen West near completely deaf. Subsequently, he turned to drawing and microscopy. 
Tuffen West's first signed illustrations that I found were lithographs and appeared in 1848 . He may have learned lithography from his younger brother William West who was a lithographer and printer in London. Tuffen West clearly had an early interest in microscopy. In an 1860 article for Recreative Science entitled "What is a diatom?", he stated that as a young man in 1850 he spent several weeks in Cork, invited by "the Professor of Natural History in the new Queen's College" (apparently William Hincks), to do illustrations of diatoms, microscope algae, using slides that had been prepared for him (West 1860a). From West's text it was his first exposure to diatoms, and he would later become an expert on them. Although we do not know when he first started using a microscope, in 1852 he was elected to the Microscopical Society of London (from 1866 the Royal Microscopical Society). His illustrations of subjects both microscopic and others, began to be published abundantly and regularly from 1853 (see Figure 1 and the following section for details).
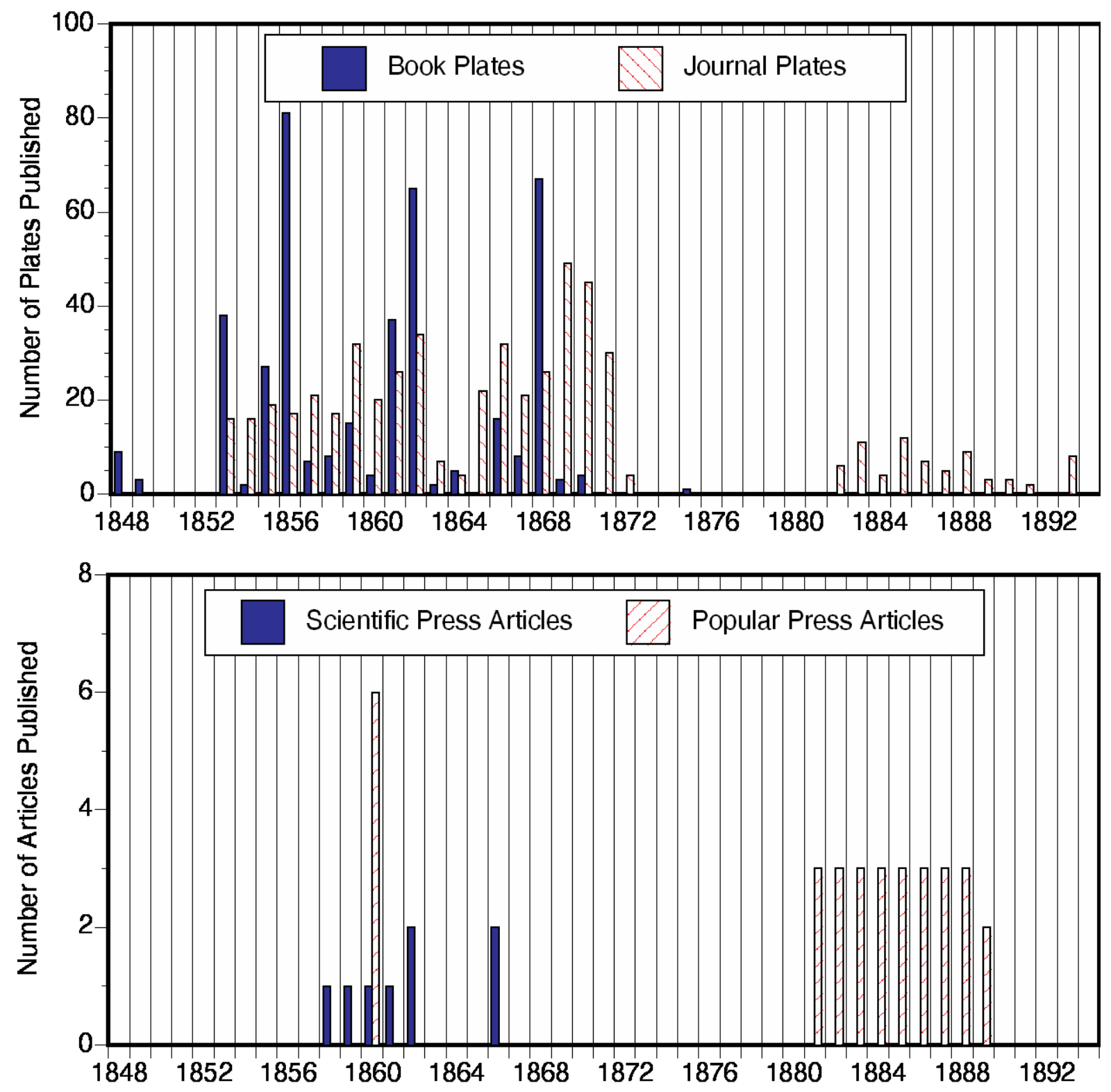

Fig. 1. Temporal distribution of the appearance of Tuffen West's illustrations, as plates in journals or books, and his articles in the scientific and popular press. Note that his work as an illustrator began before the appearance of his scientific articles. His last works, when in retirement, were articles in the popular press. As described below, the period of low productivity in the 1860's, and the abrupt end of the appearance of plates in the early 1870's, correspond to periods of his extended stays in mental institutions. A listing of the plates and publications of Tuffen West are available on simple request. 
In 1854 he married Mary Hannah Davis and their son Frederick was born in 1857. Unfortunately, he was left a widower with a young child in 1860 . However, the same year he was elected to the Linnean Society. His nomination letter described him as "a gentleman much attached to the study of natural history... and likely to prove a valuable member." It was signed by four very renowned Linnean Fellows: George Busk, William B. Carpenter, John J. Bennett, and Thomas Bell. While no doubt, "much attached to the study of natural history", in the 1861 census record Tuffen West described himself as an artisan, an "engraver and draftsman".

His illustrations nearly ceased appearing in 1863 and did not begin to appear again in large numbers again until 1865 (Fig. 1). This period of apparent professional inactivity corresponds to extended stays in mental institutions as indicated by records of the UK Lunacy Patients Admission Registers. Between December 1862 and May 1864, he was hospitalized 3 times for a total of nearly 20 months, ending at the York Retreat, a Quaker hospital for the mentally ill known for its especially humane treatment of patients. Exactly what condition he suffered from is unknown, but the periodic stays suggest the possibility of a bi-polar disorder. During all his stays he was listed as a paying patient. His production of plates for books and journal resumed by 1866 and in 1868 he married Emma Margaret Newland. However, he continued to suffer mental health problems as he returned to the York Retreat in November of 1870 for an 8-month stay. Tuffen West appeared to have ceased all activity as an illustrator in the early 1870's as neither journal nor book plates signed by Tuffen West appeared after 1872 .

In 1875, the year his son Frederick died, Tuffen West assumed the presidency of the Postal Microscopical Society and he served until 1879. The Society began in 1873 as a correspondence club for the exchange of slides among amateur microscopists and still exists as such today. The Society published the Journal of the Postal Microscopical Society in 1882-1883 and then the Journal of Microscopy and Natural Science from 1883 to 1897. Tuffen West published many articles, aimed at non-professional microscopists, in the society journals throughout most of the 1880 's. The articles included unsigned plates showing relatively crude notebook sketches. However, as explained in the section "Populiser of Microscopy" it is unclear when the articles were written and the drawings made, as well as who prepared the drawings for print. In the 1881 census, when he was but 58 years of age, he described himself as "microscopic artist, retired". Sadly, even this last part of his career was also marred by extended stays in the York Retreat. From June 1879 to July 1883 his stays totaled about 31 months. Tuffen West died in 1891 on the 19th of March at the age of 68. He was survived by his wife Emma who died in 1906.

\section{Tuffen West the Illustrator}

Appropriately, given his early collection of skeletons, the first identified published illustrations of Tuffen West (of those I found) were mostly of skeletons and appeared in books printed in 1848 . He is credited as the lithographer by Richard Owen for the plates in his "On the Archetype and Homologies of the Vertebrate Skeleton" and signed 3 plates as the lithographer in Strickland and Melville's "The Dodo and its Kindred". He produced many lithographs for works on anatomy: $A$ Manual of Pathological Anatomy Rokitansky 1854), On the Organs of Vision: Their Physiology and Anatomy (Nunneley 1858), Lectures on the Diseases of the Kidney, generally known as "Bright's Disease" and Dropsy Goodfellow 1861) the English edition (1861) of Schroeder Van Der Kolk's Case of Atrophy of the Left Hemisphere of the Brain and Hutchinson's 1863 Clinical Memoire on Certain Disease's of the Eye and Ear, Consequent on Inherited Syphilis. Tuffen West 's most substantial non-microscopic subject was spiders. He did 17 of the 29 lithographs (for example, Figure 2) for Blackwall's classic two-volume monograph A History of the Spiders of Great Britain and Ireland $(1860,1864)$. Edwin Lankester displayed some drawings from the first volume at the 1859 meeting of the British Association for the Advancement of Science, and asked that contributions of living spiders be sent to Tuffen West by post '"to enable Mr. West to continue his 
sketches from life" (Anon. 1860). Unfortunately, we do not know if he used any spiders received by post for his illustrations! He also did all 16 of the lithographs for Staveley's British Spiders (1866).

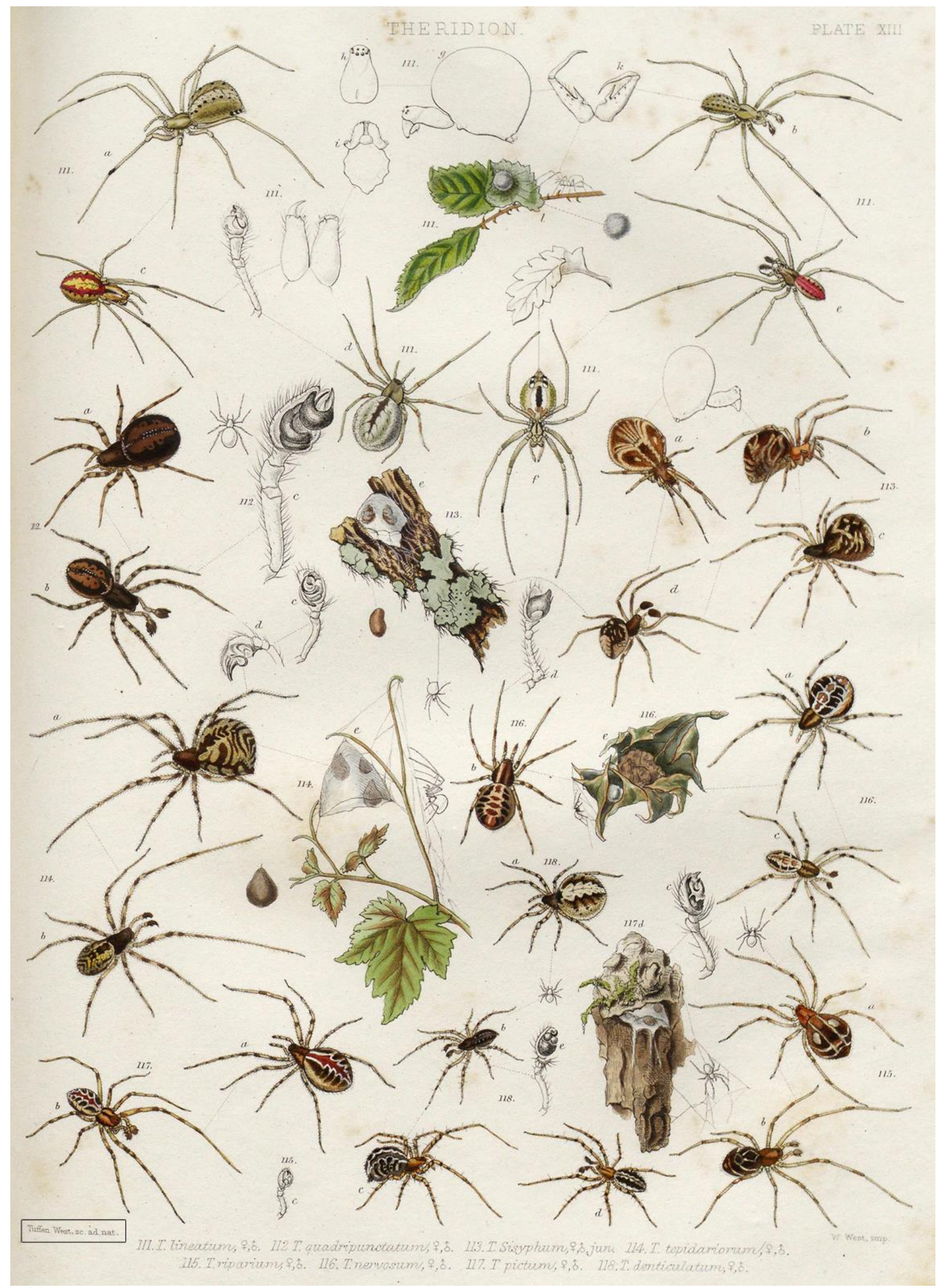

Fig. 2. Plate 13 from Blackwall's A history of the Spiders of Great Britain and Ireland, vol. 2 (1864). The text in the lower left (box added) reads "Tuffen West, sc. ad nat." indicating that he was the engraver and his illustration is 'after nature', not re-drawn from that of another person (i.e., Blackwall). The lower right inscription "W. West Imp." indicates his brother William West was the printer. The fine details shown, and somewhat crowded layout, is typical of the plates of Tuffen West. 
Although best known as an illustrator of the microscopic, it is unclear when Tuffen West began illustrating microscopic subjects. The earliest signed illustrations of microscopic subjects I found date from 1853, plates published in both journals (Quarterly Journal of Microscopical Science, Transactions of Microscopical Society of London) and a book (Smith's Synopsis of British Diatoms, vol. 1). However, according to Arthur Hassall, Tuffen West had begun illustrating microscopic subjects much earlier.

Arthur Hassall was an MD and a microscopist concerned with public health. He is probably best known for his books Food and its Adulterations and Microscopic Anatomy of the Human Body both of which appeared in many editions, with slightly different titles, into the late 1800 's. In the preface to the 1857 edition of his Food and its Adulterations entitled Adulterations detected, or, Plain instructions for the discovery of frauds in food and medicine (Hassall 1857), Hassall states that Tuffen West, then already well-known for his illustrations of the microscopic, had lived with him in the late 1840's and proudly declared that West's very first microscopic drawings were used in the first edition (1849) of his The Microscopical Anatomy of the Human Body. In the same preface, Hassall credited Tuffen West with producing about one third of the drawings used to create the 225 wood engravings in the 1857 edition of his Food and its Adulterations (Hassall 1857). Unfortunately, none of the illustrations in either of Hassall's books were signed so we've no idea exactly which 1849 or 1857 woodcut illustrations were from drawings of Tuffen West. Hassall later employed Tuffen West as the lithographer for the 27 plates for his "Report on the Microscopical Examination of different waters (principally those used in the Metropolis) during the CholeraEpidemic of 1845" (Hassall 1855).

Tuffen West's fame as an illustrator of the microscopic can be dated to at least a few years earlier than Hassall's declarations. In 1853, in the preface of the newly established Quarterly Journal of Microscopical Science (now named the Journal of Cell Science), the editors, Edwin Lankester and George Busk (who would later be the first signatory of West's nomination to the Linnean Society), congratulate themselves for having secured the services of Mr. Tuffen West for the production of lithographic plates and wood cuts for the journal (Lankester \& Busk 1853). From 1853 to 1871 he produced plates for many major journals: the Quarterly Journal of Microscopical Science, Transactions of the Microscopical Society of London (and its later incarnations as Transactions of the Royal Microscopical Society and the Monthly Microscopical Journal), Transactions of the Linnean Society of London, Philosophical Transactions of the Royal Society, Annals and Magazine of Natural History, and the Popular Science Review. One of his major works was producing the illustrations for Smith's Synopsis of British Diatomaceae (Smith 1853,1856), 67 plates of drawings 'from nature' (e.g. Fig. 3). The project occupied him for 5 years (Anon. 1891). 


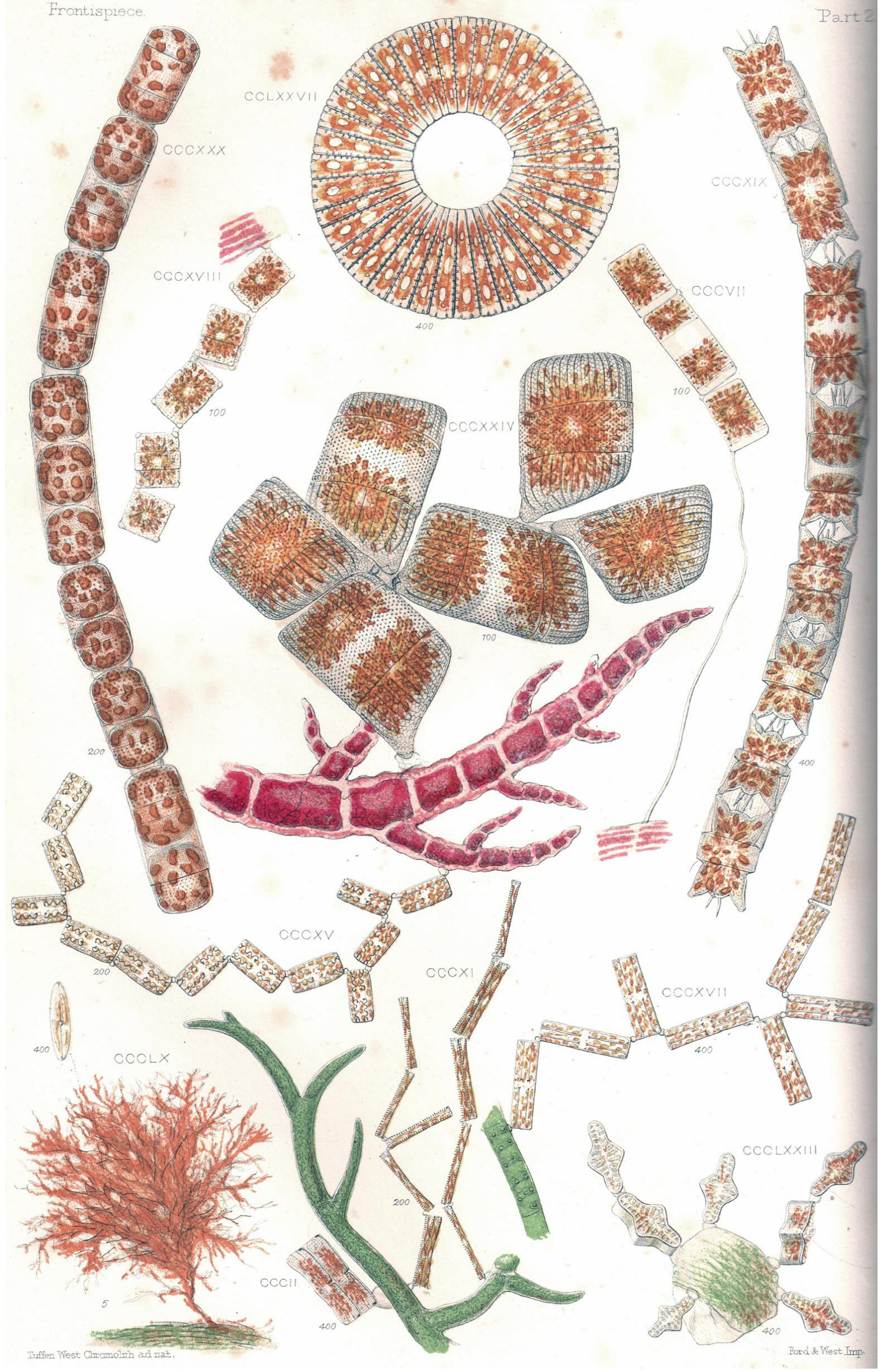

Fig. 3. The frontispiece of the second (1856) volume of Blackwall's Synopsis of British Diatomaceae. Note that inscription in the lower left indicates that Tuffen West drew the illustrations from nature. 
In quantitative terms, Tuffen West produced at least 528 plates for journals, significantly more than the number of plates printed in books, 410. Many of his plates were signed "ad nat." (after nature) indicating the illustrations were based on his own drawings of the subjects shown. The numbers of plates should be considered minimal estimates as only signed plates were included, or those attributed to West by the author, generally in a preface (e.g. Owen in his "On the Archetype and Homologies of the Vertebrate Skeleton) or in the legend to the plate. It is quite likely that some works were over-looked.

The production of the about 1000 plates over the period from 1853 to 1872 would equate to an average output of around 50 per year, which would not have created a substantial income typical of a married professional (Richard Goddard, of Goddard 2016, pers. comm.). This suggests that he either produced many more drawings and plates than have been identified to date, or that he had another source of income, since he left a substantial estate of $£ 5,000$ when he died (Baker et al. 2014).

While Tuffen West produced hundreds of plates, he is probably best known today for the handful of plates he did for two very popular books: Half Hours with the Microscope, first published in 1859 and Common Objects of the Microscope first published in 1861. However, he was much more than a simple illustrator for both books. The stories of the genesis of these works show that Tuffen West's illustrations provided their basis.

The story of the first book, Half Hours at the Microscope, appeared only in Edwin Lankester's preface to the second, 1860 edition. It is reproduced in its entirety below.

\section{NOTICE TO SECOND EDITION.}

The design of this work is due to Mr. Hardwicke, who requested me to write the text, applying, at the same time, to Mr. Tuffen West to give him a series of illustrations. My time being so much occupied, I recommended Mr. Hardwicke to apply to a gentleman highly competent to execute the task. After some time, this gentleman was obliged, on account of other engagements, to relinquish it, and I then undertook to write an accompanying text to Mr. West's excellent plates. The work has been very favourably received by the public. I have only now consented to acknowledge my share in it, at the earnest request of the publisher, as I feel its chief merit is due to Mr. West's successful illustrations. In this edition I have corrected some trifling errors, and added some fresh matter, chiefly at the suggestion of Mr. West, Mr. Joshua Alder and other friends.

\section{E. Lankester}

The 'Notice to the Second Edition' clarified the authorship of the first (and now quite rare) 1859 edition that was attributed soley to Tuffen West (Figure 4.) In second and subsequent editions, the authorship is attributed to Edwin Lankester, with illustrations by Tuffen West. All of the editions following the 1860 second edition omitted the 'notice to second edition' given above. Consequently, the fact that the book was written around Tuffen West's 8 plates is not well known. In fact, the editions that appeared after the 1876 edition (up to and including the last one dated 1892) omit West's name from title page as well. 


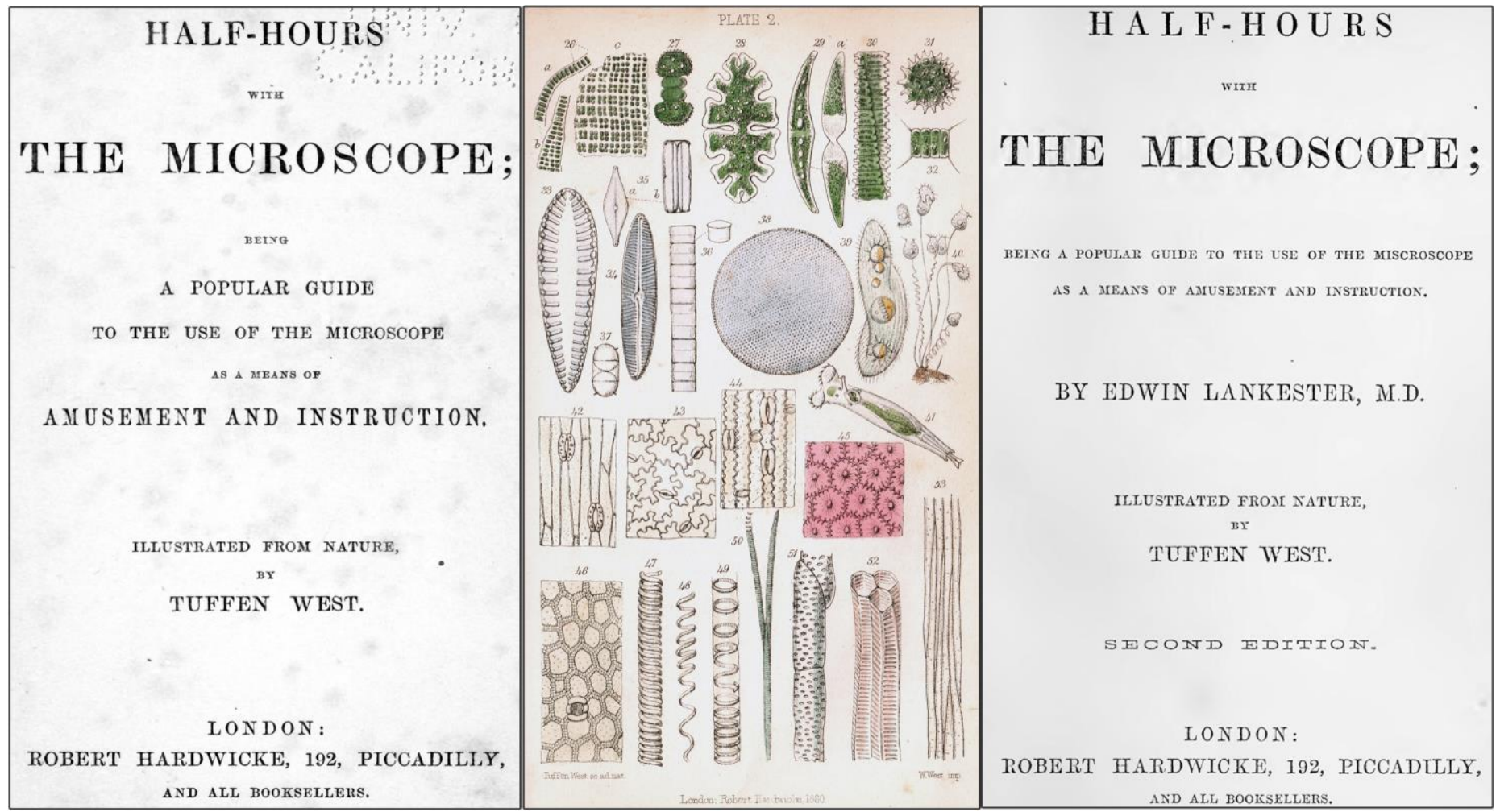

Fig. 4 Half-Hours with the Microscope: The left panel show the title page from the first 1859 edition which lists only Tuffen West (West 1859a). The middle panel is the plate for the chapter "at the pond-side" showing West's choices of microscopic subjects from a pond. The right panel shows the title page from the second, 1860, edition that attributed authorship to Edwin Lankester and the illustrations to West.

The second popular book on microscopy based on Tuffen West's plates was Common Objects of the Microscope which was first published in 1861. It was authored by John G. Wood, one of the best most known populizers of science in the Victorian era (Lightman 2012). His Common Objects of the Seashore first appeared in 1857 and was followed by Common Objects of the Country in 1858. Common Objects of the Country was one of the best selling titles in the last half of the 19th century (Lightman 2012). Common Objects of the Microscope was the last of the Common Objects series. The preface reveals that, like Half-Hours with the Microscope, the book was written around Tuffen West's 12 plates as indicated in the last paragraph of the preface to the first edition, which is reproduced below.

Owing to the many claims on my time, I left the selection of the objects to Mr. Tuffen West, who employed the greater part of a year in collecting specimens for the express purpose, and whose well- known fidelity and wide experience are the best guarantees that can be offered to the public. To him I also owe many thanks for his kind revision of the proof-sheets. My thanks are also due to Messrs. G. and H. Brady, who lent many beautiful objects, and to Messrs. Baker, the well-known opticians of Holborn, who liberally placed their whole stock of slides and instruments at my disposal.

Not only was Tuffen West the illustrator of the book, he was responsible for the choice of objects and specimens to be shown. Thus, the text was written around his plates, as it was in Half-Hours at the Microscope, and he also corrected the proofs of the book. Considering his contributions, Tuffen West was given relatively meager credit on the title page, on a par with the printer of the plates (Fig. 5). Nonetheless, the value of his illustrations in selling the book can be seen in the cover of the 1900 one shilling edition, with black and plates, featuring prominently "Illustrated by Tuffen West" (Fig. 5). Interestingly, a third edition, 'revised and re-written by W. J. Ferrier' was published in 1938, and reprinted in 1949, omitting Wood's preface and making no mention of Tuffen West. Thus, in the last 
editions of both Half-hours with the Microscope and Common Objects of the Microscope, Tuffen West's contributions were omitted entirely.

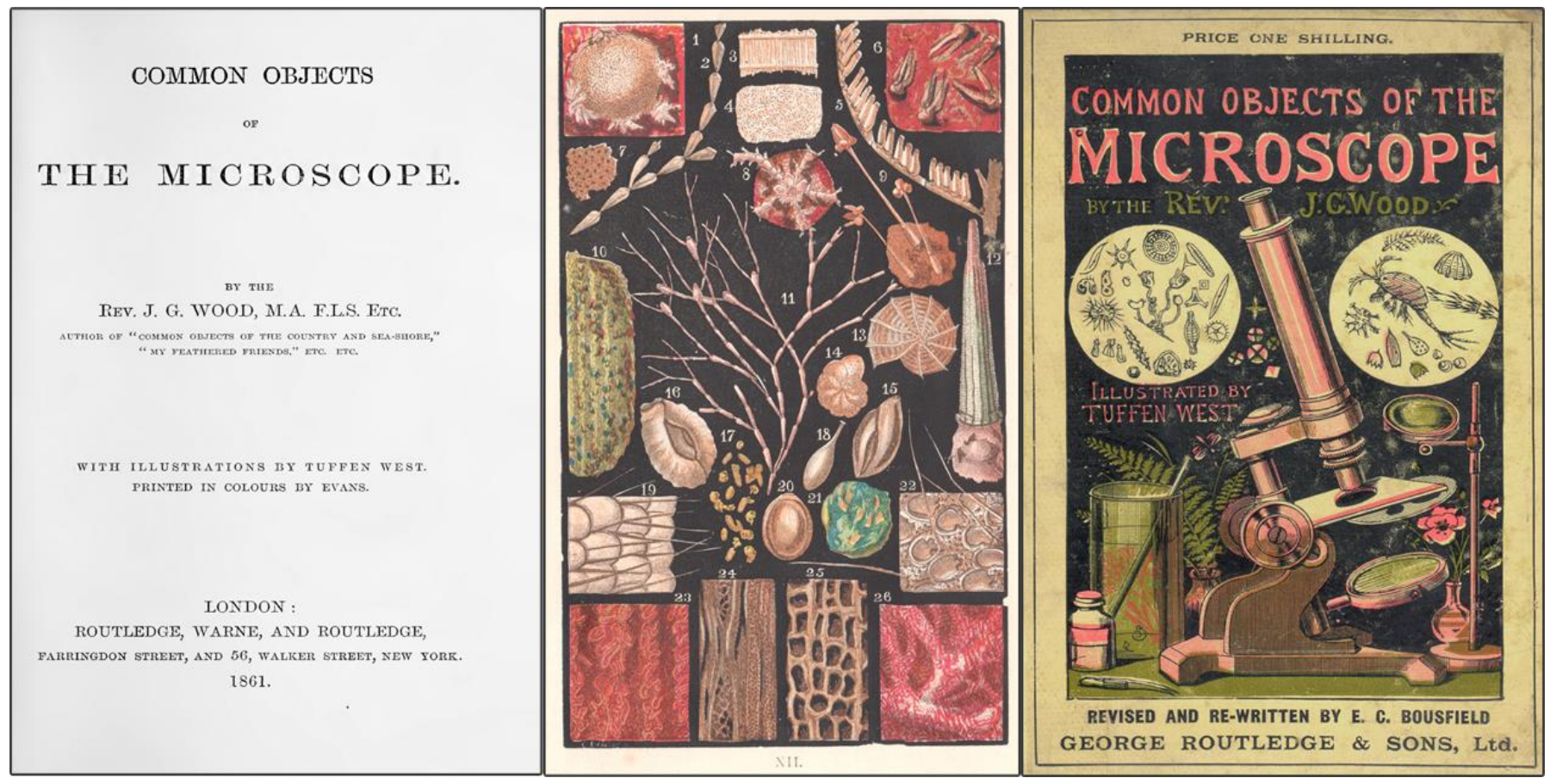

Fig. 5. Common Objects of the Microscope: The left panel show the title page from the first 1861 edition which lists Tuffen West as the illustrator while giving equal prominence to Evan, the printer. The middle panel is the plate for the chapter "at the seashore". The right panel shows the cover of the inexpensive version of the third edition (published in 1900) that mentions 'Illustrated by Tuffen West'. While the cover was colorful, the plates were monochromatic.

\section{Tuffen West the Naturalist}

Tuffen West authored several articles in the scientific press (Table One) and presented papers in meetings of the British Association for the Advancement of Science. Most of the articles reported on his observations of microscopic structures and morphology. The articles concerned a wide range of subjects: plants, insects, spiders and microscopic algae. Naturally, the illustrations accompanying the articles were masterful (e.g., Fig. 6). While some articles were apparently never cited, some continue to be cited as recently as in 2020 and 2021. For example "Remarks on some Diatomacex, new or imperfectly described, and a new Desmid" is cited in Stonik \& Efimova (2020) and by Kaczmarska \& Ehrman (2021); "The foot of the fly; its structure and action: elucidated by comparison with the feet of other insects, etc. " is cited in Kimura et al. (2020). Thus, it is difficult to ignore his work as a naturalist as it is still referenced today. To Tuffen West, his work as a naturalist was of great importance to himself. The anonymous memorium of 1891 states that of all of his work, the one West most proud of was his article "The Foot of the Fly....". 
Table 1. Scientific Publications of Tuffen West

\begin{tabular}{|c|c|c|c|}
\hline Title & Journal & Cites & Reference \\
\hline $\begin{array}{l}\text { On the structure of Rhabdonema and other Diatomaceae with } \\
\text { compound frustules }\end{array}$ & QJMS & 0 & West 1858 \\
\hline $\begin{array}{l}\text { On some Conditions of the cell-wall in the petals of flowers, with } \\
\text { remarks on some so-called external secondary deposits }\end{array}$ & QJMS & 0 & West $1859 b$ \\
\hline On the epidermal cells of the petals of plants (abstract) & BAAS & 0 & West $1859 \mathrm{c}$ \\
\hline $\begin{array}{l}\text { Remarks on some Diatomaceæ, new or imperfectly described, and } \\
\text { a new Desmid }\end{array}$ & TMSL & 33 & West $1860 \mathrm{~b}$ \\
\hline $\begin{array}{l}\text { On certain appendages to the feet of insects subservient to holding } \\
\text { or climbing }\end{array}$ & JPLSZ & & West $1862 \mathrm{a}$ \\
\hline $\begin{array}{l}\text { The foot of the fly; its structure and action: elucidated by } \\
\text { comparison with the feet of other insects, etc. }\end{array}$ & TLSL & 38 & West $1862 b$ \\
\hline On Some Points of Interest in the Structure and Habits of Spiders & BAAS & 0 & West $1862 c$ \\
\hline On the structure of the egg in Scatophaga & TMSL & 0 & West $1866 \mathrm{a}$ \\
\hline $\begin{array}{l}\text { Description of the skin cast by an ephemeron, in its 'Pseud- } \\
\text { Imago'condition. }\end{array}$ & TMSL & & West $1866 b$ \\
\hline On the structure of the testa of the seed of Solanaceae & JB & 6 & West $1866 c$ \\
\hline
\end{tabular}

Journal abbreviations: QJMS $=$ Quarterley Journal of Microscopical Science, TMSL = Transactions of the Microscopical Society of London, JPLSZ = Journal of the Proceedings of the Linnean Society Zoology, TLSL = Transactions of the Linnean Society of London, BAAS = meeting reports of the British Society for the Advancement of Science, JB = Journal of Botany. Complete references are given in the Reference section. Citation data from Google Scholar on March 5th 2021. 


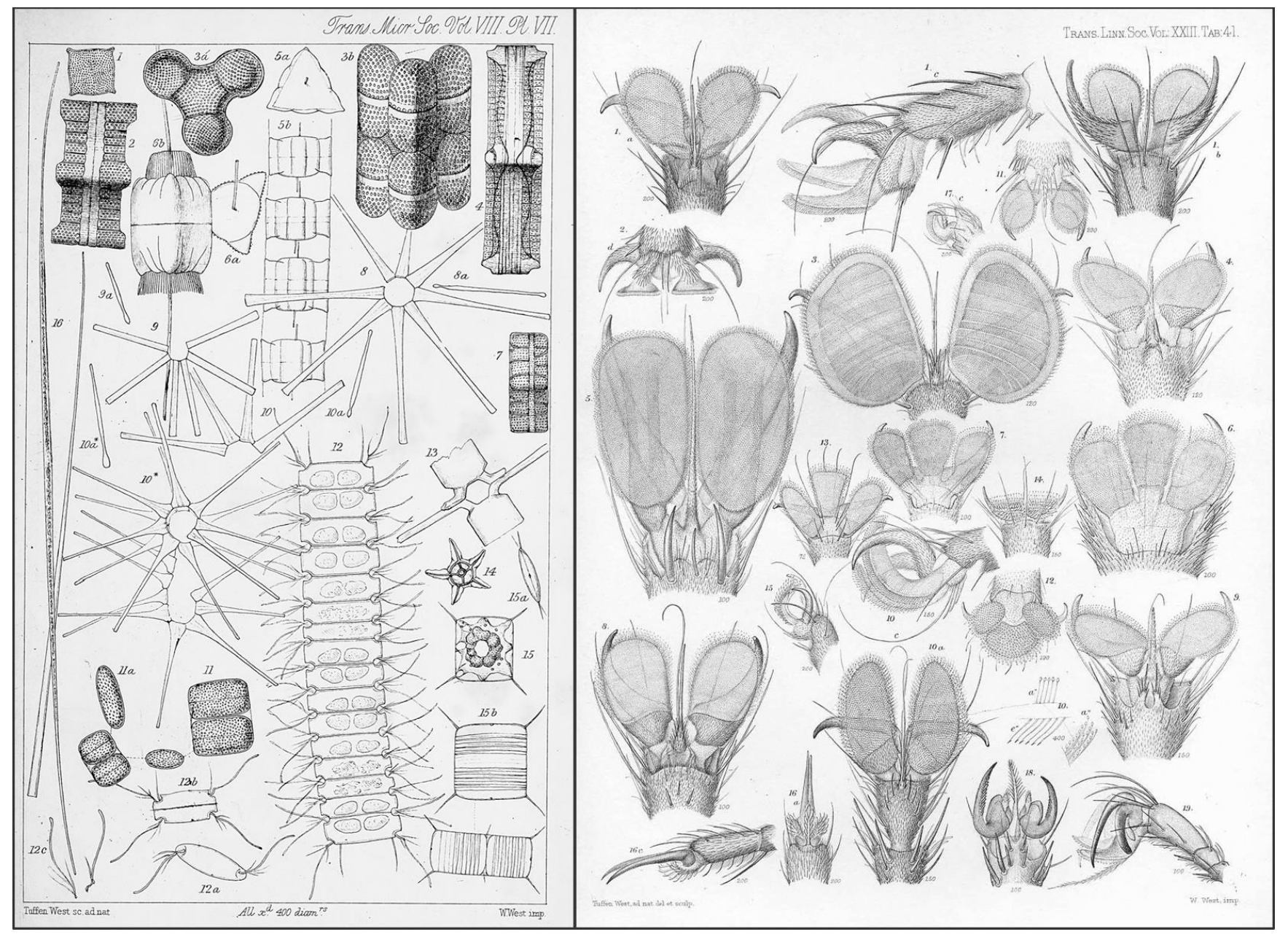

Fig. 6. Left panel: the plate from Tuffen West's article on Diatomaceae (West 1860a); Right Panel one of the 2 plates illustrating his article on the foot of the fly (West 1862b), the work in which he took the most pride, it was said (Anon. 1891).

\section{Tuffen West the Populiser of Microscopy}

Tuffen West began writing on microscopy and microscopic investigations for the general public in 1860 in a series of charming articles published in Recreative Science (see Table Two). The articles were on diatoms, what they are, how to collect them, how to prepare them for microscopic examination, examining crystals found in plants, and perhaps most prosaically, 'The Wonders of a Stagnant Pool'. Remarkable is that 1860 was period of intense professional activity for West judging by the appearance of both plates bearing his name and articles in the scientific press (see Fig. 1). He only returned to publishing in the popular press after retirement during the 1880's.

Tuffen West's articles were a regular and important feature of the publications of the Postal Microscopical Society, founded as an association for the exchange of microscope slides and the observations of it members. According to a notice in the first issue of the Journal of the Postal Microscopical Society, the society's journal was created to bind the together the geographically farflung members of the society and

"A desire was also manifested to utilise in some way the valuable Notes and original Drawings by Mr. Tuffen West, Mr. Hammond, and others, which have hitherto lain buried in disused Note-books ; and to put them into such general circulation, ...." (Allen, 1882).

Tuffen West's articles appeared, at first, under the heading "An Hour at the Microscope" in 1882 and then from 1883 to 1893 as "Half an Hour at the Microscope" obviously referencing the book 
"Half hours with the Microscope". Ironically in 1889, When Tuffen West's articles "Half an Hour at the Microscope" were still appearing regularly, the 16th edition of the book appeared in which West's name is entirely absent. Some two years after his death in 1891, two articles appeared and only in 1896, with the appearance of the last article is the authorship noted as "Half-Hours at the Microscope with the late Mr. Tuffen West".

The articles were published in the 1880's and 1890's (see Table Two) but it is not clear when they were written. The first appeared, prefaced with unsigned note given below, presumably written by the editor, Alfred Allen. It states that the material published are the notes Tuffen West wrote concerning the microscope slides he examined while he was President of the Postal Microscopical Society, which was from 1875 to 1879 . The note also mentions West's 'long and serious illness', presumably his mental condition, which prevented him from working. As mentioned above in the Biographical Sketch above, he spent a considerable amount of time at the York Retreat between 1879 and 1883.

An Hour at the Microscope, with Mr. Tuffen West, F.L.S., F.RM.S., etc.

UNDER this heading it is proposed to give, in successive numbers of the Journal, selections from the full and varied Notes written by Mr. West on the numerous slides which passed through his hands whilst President of the Society. They will serve to show, in his own words, his general method of dealing with a box of slides, his arrangement of their contents, his kindly criticisms, his genial and instructive comments upon each object passed in review before him, as well as the vast stores of information which he had ever at command on every subject connected with the Microscope. The long and serious illness that has for the present laid him entirely aside from all work, and deprived the Society of his valuable help, is an event deeply to be lamented, not by this Society alone, but by all who are interested in Microscopic pursuits.

The 1860 articles were published in Recreative Science; the articles from 1882 and 1883 appeared in the Journal of the Postal Microscopical Society; articles from 1884 to 1896 appeared in the Journal of Microscopy and Natural Science. Complete references are available on simple request. 


\begin{tabular}{|c|c|}
\hline Title & Reference \\
\hline Diatoms: How to gather diatoms & West $1860 \mathrm{~b}$ \\
\hline Diatoms: How to examine and prepare for the microscope & West $1860 \mathrm{c}$ \\
\hline What is a diatom? & West $1860 \mathrm{~d}$ \\
\hline Wonders of a stagnant pool & West $1860 \mathrm{e}$ \\
\hline Raphides, or microscopic plant-crystals & West $1860 f$ \\
\hline Norbert's test-lines & West $1860 \mathrm{~g}$ \\
\hline An hour at the microscope: Method, arrangement, classification & West $1882 \mathrm{a}$ \\
\hline An hour at the microscope: Diatoms. & West $1882 \mathrm{~b}$ \\
\hline An hour at the microscope: Funaria hygrometrica & West $1882 \mathrm{c}$ \\
\hline Half an hour at the microscope: Polystoma crispa & West $1883 \mathrm{a}$ \\
\hline Half an hour at the microscope: Yucca recurva & West $1883 b$ \\
\hline Half an hour at the microscope: Epithemia argus & West $1883 \mathrm{c}$ \\
\hline Half an hour at the microscope: On placing slides into the boxes & West $1884 \mathrm{a}$ \\
\hline Half an hour at the microscope: Sting of scorpion & West $1884 \mathrm{~b}$ \\
\hline Half an hour at the microscope: Black-ground illumination & West $1884 \mathrm{c}$ \\
\hline Half an hour at the microscope: Plagiogramma & West $1885 \mathrm{a}$ \\
\hline Half an hour at the microscope: Crystals of strychnine & West $1885 b$ \\
\hline Half an hour at the microscope: Sphaeria & West $1885 \mathrm{c}$ \\
\hline Half an hour at the microscope: Seeds of Campanula cartatica & West $1886 \mathrm{a}$ \\
\hline Half an hour at the microscope: Catenicella ventricosa & West $1886 \mathrm{~b}$ \\
\hline Half an hour at the microscope: Flint & West $1886 c$ \\
\hline Half an hour at the microscope: Longitudinal section of Alder & West $1887 \mathrm{a}$ \\
\hline Half an hour at the microscope: Parasite of Gull, Docophorus platygaster & West $1887 \mathrm{~b}$ \\
\hline Half an hour at the microscope: Aecidium compositarium & West $1887 \mathrm{c}$ \\
\hline Half an hour at the microscope: Onosma tauricus & West 1888a \\
\hline Half an hour at the microscope: Marine diatoms in situ & West $1888 \mathrm{~b}$ \\
\hline Half an hour at the microscope: Phthirius inguinalis & West $1888 \mathrm{c}$ \\
\hline Half an hour at the microscope: Stauroneis fulmen & West $1889 \mathrm{a}$ \\
\hline Half an hour at the microscope: Lady-bird mouth & West $1889 \mathrm{~b}$ \\
\hline Half an hour at the microscope: True avanturina & West $1889 \mathrm{c}$ \\
\hline Half an hour at the microscope: The fungus on sow-thistle & West 1890a \\
\hline Half an hour at the microscope: Section of spine of Echinus & West $1890 \mathrm{~b}$ \\
\hline Half an hour at the microscope: Foraminifera from Atlantic Soundings & West 1891a \\
\hline Half an hour at the microscope: Laap & West $1891 \mathrm{~b}$ \\
\hline Half an hour at the microscope: Stellate hairs amongst the sori of Platycerium alcicorne & West 1893a \\
\hline Half an hour at the microscope: Callithamnion roseum & West $1893 \mathrm{~b}$ \\
\hline Half an hour at the microscope: Arborescent crystallised silver & West 1896 \\
\hline
\end{tabular}


The articles in the journals of the Postal Microscopy Society were then apparently from Tuffen West's notebooks. We do not know who chose the texts and illustrations, if they were published in some sort of order, or if any editing was done. Oddly enough, they were not all authored by Tuffen West: one of the articles published in 1866 as a Half Hour at the Microscope by Tuffen West (West 1866c) was signed by his wife, Emma "Sept 1878 E.M. West" with a note from the editor saying that while the text was by Emma West the editor believed the illustration was by Tuffen West. All of the plates accompanying the articles were fairly rough notebook sketches (e.g. Fig . 6), compared to the plates published in earlier years. Regardless of the pathway to publication, the articles in the Postal Microscopical Society's journals represented a very substantial contribution to the popularization of microscopy, in aggregate, 127 pages of text and 70 plates were published under the name of Tuffen West. 


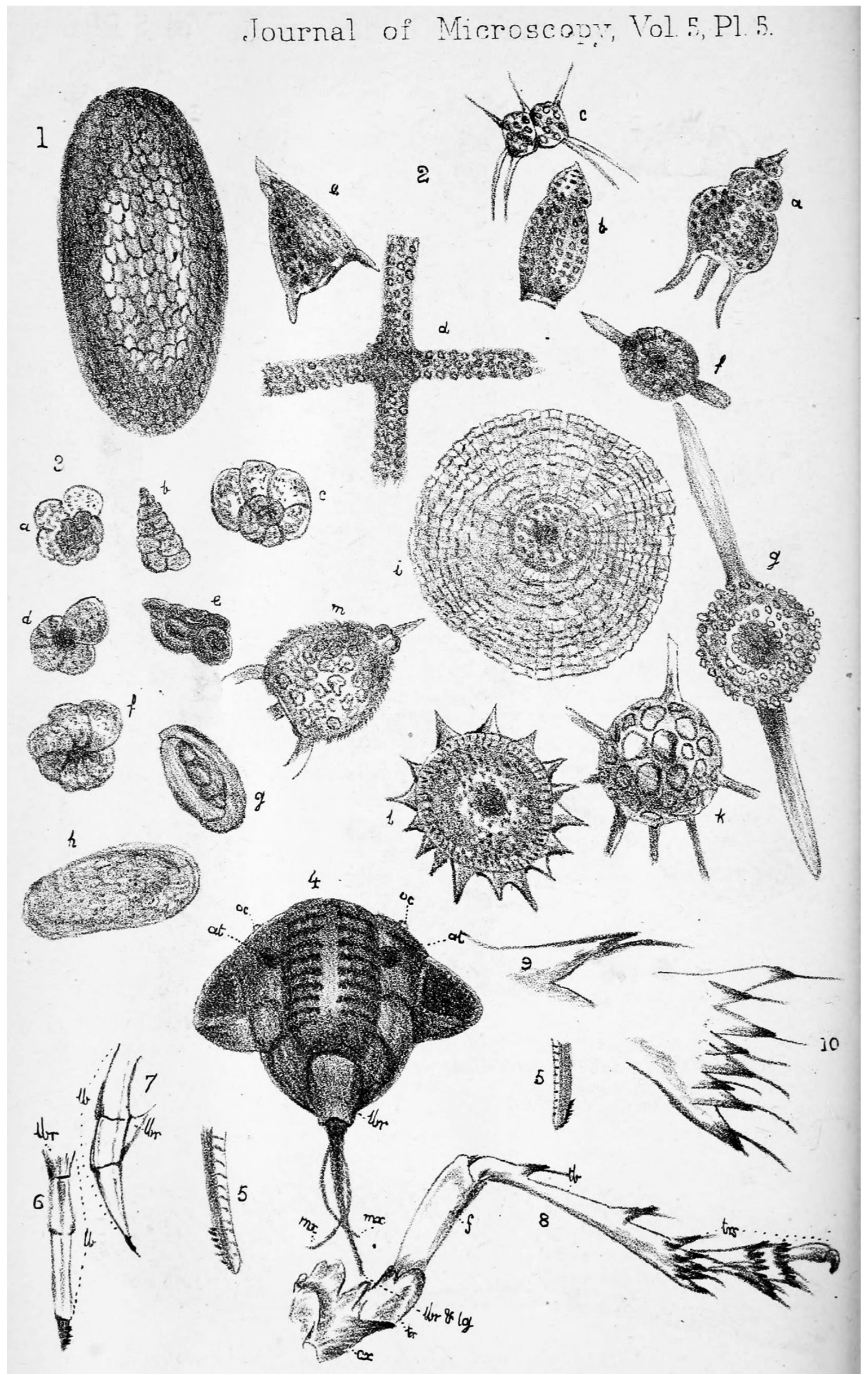

Fig. 7. The plate from one of Tuffen West's Half an Hour at the Microscope articles (West 1886a) illustrating a seed, radiolaria and foraminfera and anatomy of an insect. The plates, drawings from a notebook, differed considerably from those he made for scientific publications (e.g., Fig. 6). 


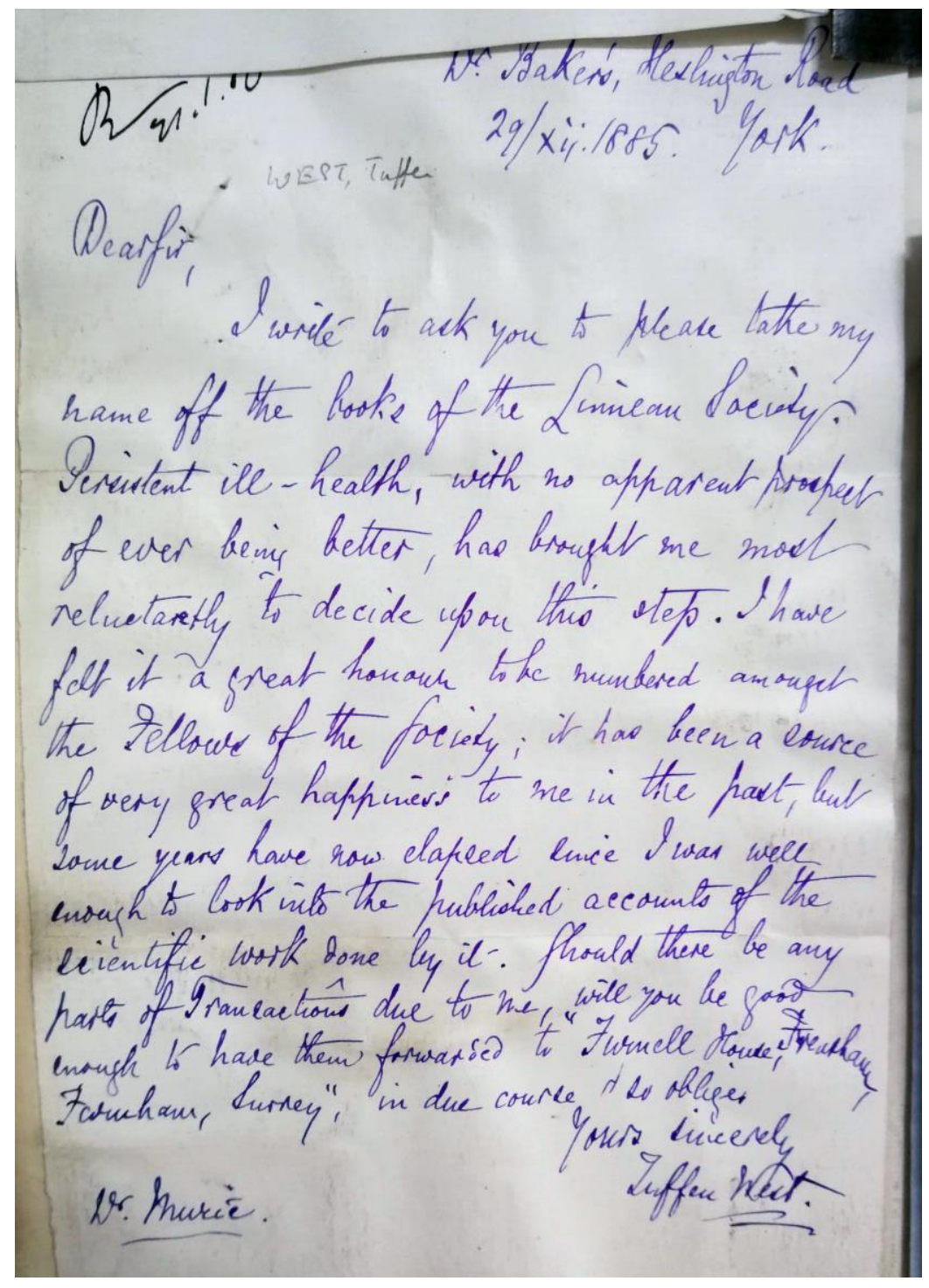

Fig. 8. Tuffen West's 1885 letter to the Linnean Society regretfully asking to resign from the Linnean Society due to his ill health and saying he is no longer able to follow the scientific accounts in the society's journals. It seems possible that by 1886 he was not writing or editing the articles published in the Journal of Microscopy and Natural Science under his name as they continued to be authored as by 'Tuffen West FLS' Image of the letter is published with the permission of the Linnean Society of London.

\section{Conclusion}

Tuffen West, is acknowledged as a master illustrator of the microscopic. Hopefully shown here is the rarely appreciated fact that he was more than a skilled draftsman. He was a naturalist in his own right. He was a Fellow of the Linnean Society and a Fellow of the Royal Microscopical Society. His scientific papers are still cited today. Tuffen West was also a very active popularizer of microscopy. His accomplishments as an illustrator, as a naturalist, and as a populizer of microscopy are all the more remarkable when one considers that his life was riddled with losses. First his hearing loss as young man (1845), then his first wife's death leaving him a widower with a 3 year-old son (1860), his chronic mental health problems (asylum stays totaling 60 months), and the loss of his son who was but 18 years old (1875).

\section{Acknowledgements}

Richard Goddard provided valuable information concerning the compensation of lithographers in the mid 19th century and commented on a previous version of the manuscript. The comments of an 
anonymous reviewer and the Editor led to significant improvements in the manuscript. Nonetheless, I retain full credit for any errors of fact or interpretation.

Andrea Deneau, of the Linnean Society of London, kindly made the arrangements to provide me with a copy of Tuffen West's letter of nomination to the Linnean Society and provided aid in deciphering the signatures allowing identification of the illustrious nominators as well obtaining a copy of the Tuffen West letter shown in Figure 8. Census records, birth, marriage, burial, probate records, as well as the records of the UK Lunacy Patients Admission Registers, were accessed using Ancestry.co.uk on February 5, 2020

The 3 articles below by Peter B. Paisley M.D. (deceased June 25 2019) in the magazine of microscope enthusiasts, Miscape Magazine, helpfully identified many anatomical works illustrated by Tuffen West. I regret not being able to share the present work with him. However, some information is given in his articles that I was unable to verify, especially concerning William West.

The Tuffen you probably missed, and some you've never seen - by Peter Paisley (2015) Published in the September 2015 issue of Micscape magazine., www.micscape.org

More Tuffen you possibly didn't notice - by Peter Paisley, (2016) Published in the February 2016 issue of Micscape magazine., www.micscape.org

Tuffen's artistic brother, William West - by Peter Paisley (2017) Published in the February 2017 issue of Micscape magazine., www.micscape.org

\section{References}

Allen, A. 1882. To our readers. Journal of the Postal Microscopical Society, 1: unnumbered front matter.

Anon. 1842. The Arranged Catalogue of the Library of the Mechanic's Institute, Gateshead: William Douglas, $40 \mathrm{pp}$,

Anon. 1860. untitled. Report of the British Association for the Advancement of Science Held at Aberdeen in September 1859 , pg 150.

Anon. 1891. The late Mr. Tuffen West, F.R.M.S. Journal of the Royal Microscopical Society, 1891, Part 4. 529-532

Blackwall, J. 1860. A history of the Spiders of Great Britain and Ireland, Part I. London: Published for the Ray Society by Robert Hardwicke, pg 1-174.

Blackwall, J. 1864. A history of the Spiders of Great Britain and Ireland, Part II. London: Published for the Ray Society by Robert Hardwicke, pg 175-384 pp.

Cheetham, W., Reynolds,R. 1889. William West, F.R.S. Proceedings of the Yorkshire Geological and Polytechnic Society, 10:238-240.

Goddard, R. 2016. Drawing on Copper: The Basire family of copper-plate engravers and their works. Maastricht: Print Datawyse, Universitaire Pers Maastricht.

https://cf217bb1-2e31-40ae-9fee-eafd4327025c.filesusr.com/ugd/a5bf58_f6385540cf8b44f282fd2db5df612590.pdf

Goodfellow, S.J. 1861. Lectures on the Diseases of the Kidney, generally known as "Bright's Disease" and Dropsy. London: Robert Hardwicke, 308 pp.

Hutchinson, J. 1863. A Clinical Memoir of Certain Diseases of the Eye and Ear consequent on Inherited Syphilis. London: John Churchhill, 259 pp.

Hassall, A.H. 1849. The microscopic anatomy of the human body in health and disease. Vol 1. London: S. Highley, $570 \mathrm{pp}$.

Hassall, A.H. 1855. Report of the microscopical examinations of different waters (principally those used in the metropolis) during the cholera-epidemic of 1845. Appendix VIII., pg 216- 283, in "Appendix to Report of the Committee for Scientific Inquires in relation to the Cholera-Epidemic of 1854. London George E. Eyre and William Spottiswoode, $352 \mathrm{pp}$. 
Hassall, A.H. 1857. Adulterations detected, or, Plain instructions for the discovery of frauds in food and medicine. London: Longman, Brown, Green, Longmans and Roberts, 712 pp.

Hutchinson, J. 1863. A Clinical Memoir of Certain Diseases of the Eye and Ear consequent on Inherited Syphilis. London: John Churchhill, 259 pp.

Kacmarska, I., Ehrman, J.M. 2021. Enlarge or die! An auxospore perspective on diatom diversification. Organism Diversity and Evolution, 21: in press. https://doi.org/10.1007/s13127-020-00476-7

Kimura, K., Minami, R., Yamahama, Y. Hariiyama, T. Hosoda, N. 2020. Framework with cytoskeletal actin filaments forming insect footpad hairs inspires biomimetic adhesive device design. Communications Biology, 3:272. doi:10.1038/s42003-020-0995-0

Lankester, E., Busk, G. 1853. Preface. Quarterly Journal of Microscopical Science, 1:1-2.

Lankester, E. 1860. Half-hours with the microscope (2nd ed). London: Robert Hardwicke, 92 pp

Lightman, B. 2012. Communicating knowledge to new audiences: victorian populizers of science. Proceedings of the Nova Scotian Institute of Science, 47: 5-31

Lightman, B. 2016. Populizers, participation and the transformation of nineteenth-century publishing from the 1860's to the 1880's. Notes and Records, 70:343-359. doi:10.1098/rsnr.2016.0029

Morrell, J. Thackray, A. 1981. Gentlemen of Science: Early Years of the British Association for the Advancement of Science. Oxford: Oxford University Press, 592 pp.

Nunneley, T. 1858. On the Organs of Vision: Their Anatomy and Physiology. London: John Churchill, 373 pp.

Owen, R. 1848. On the Archetype and Homologies of the Vertebrate Skeleton. London: Richard and John E. Taylor, 202 pp.

Rokitansky, C. 1854. A Manual of Pathological Anatomy, Vol 1. London: Sydenham Society, 410 pp.

Schroeder van der Kolk, J.L.C. 1861. Case of Atrophy of the left hemisphere of the brain, with coexistent atrophy of the right side of the body. London, New Sydenham Society, $175 \mathrm{pp}$.

Smith, W. 1853. A synopsis of the British Diatomacea : with remarks on their structure, functions and distribution; and instructions for collecting and preserving specimens. Vol. 1. London, J. Van Host, $89 \mathrm{pp}$.

Smith, W. 1856. A synopsis of the British Diatomacea: with remarks on their structure, functions and distribution; and instructions for collecting and preserving specimens. Vol. 2. London, J. VanHost, $170 \mathrm{pp}$.

Staveley, E.F. 1866. British Spiders: an introduction to the study of the Araneidae of Great Britain and Ireland. 280 pp.

Stonik, I.V., Efimova, K.V. 2020. Attheya (Bacillariophyta) from the northwestern Sea of Japan: a description of two subgenera based on molecular and morphological data. Phycologia 59:227-237. doi.org/10.1080/00318884.2020.1732801

Strickland, H.E., Melville, A.G. 1848. The Dodo and its Kindred or the History, Affinities, and Osteology of the Dodo, Solitaire and other Extinct Birds of the Islands of Maurituis, Rodriguiz, and Bourbon. London: Reeve, Benham, and Reeve, $141 \mathrm{pp}$.

Turner, G. L'E. 1974. Microscopical communication. Journal of Microscopy 100:3-20. doi:10.1111/j.13652818.1974.tb03910.x

West, T. 1858. On the structure of Rhabdonema and other Diatomaceae with compound frustules. Quarterly Journal of Microscopical Science, 6:186-188.

West, T. 1859a. Half-hours with the Microscope, Illustrated from Nature. London: Robert Hardwicke, 84 pp.

West, T. 1859b. On some Conditions of the cell-wall in the petals of flowers, with remarks on some so-called external secondary deposits. Quarterly Journal of Microscopical Science, 7:22-26.

West, T. 1859. On the epidermal cells of the petals of plants. Report of the Twenty-eighth Meeting of the British Association for the Advancement of Science Held at Leeds in September 1858, London: John Murray, pg 119 (abstract).

West, T. 1860a. What is a diatom? Recreative Science, 1: 85-89. 
West, T. 1860b. Remarks on some Diatomaceæ, new or imperfectly described, and a new Desmid. Transactions of The Microscopical Society 8:147-153.

West, T. 1862a. On certain appendages to the feet of insects subservient to holding or climbing. Journal of the Proceedings of the Linnean Society, 6:26-28

West, T. 1862b. The foot of the fly; its structure and action: elucidated by comparison with the feet of other insects, etc-Part I. Transactions of the Linnean Society, London. 23: 393-421

West, Tuffen 1862c. 'On Some Points of Interest in the Structure and Habits of Spiders', Report of the Thirty-First Meeting of the British Association for the Advancement of Science held at Manchester in September 1861, London: John Murray, Notes and Abstracts of Miscellaneous Communications to the Sections, 162-64.

West, T. 1866a. On the structure of the egg in Scatophaga. Transactions of The Microscopical Society, 14:67-68.

West, T. 1866b. Description of the skin cast by an ephemeron, in its 'Pseud-Imago' condition. Transactions of The Microscopical Society, 14: 69-70. http

West, T. 1866c. On the structure of the testa of the seed of Solanaceae. Journal of Botany, British and Foreign, 4:208.

Wood, J.G. 1857. The Common Objects of the Sea Shore : Including Hints for an Aquarium. London: George Routledge and Sons, 204 pp.

Wood, J.G. 1858. Common Objects of the Country. London: G. Routledge \& Co, 96 pp.

Wood, J.G. 1861. Common Objects of the Microscope. London: George Routledge Warne and Routledge, 186 pp.

Wood, J.G. 1938. Common Objects of the Microscope (3rd ed) Revised and re-written by W.J. Ferrier. London: Routledge \& Kegan Paul ltd, 184 pp. 